depend upon some influences exerted on the epiphysial cartilages by the disease. The lengthening is due to the prolonged hyperamia attendant upon necrosis extending to the epiplysial cartilage, and giving an inpetus to the eell formation there; anul it is most frequent in the tibia, because the neerosis in that bone frequently affects the shaft; whereas in other bones the disease, in consequence of its being nearer to epiphysial eartilage, is more likely to cause destruetion of the eartilage and consequent arrest of growth. Examples are quoted in which disease of the epiphyses, oceurring in affeetions of joints, was attenderl with elongation of the bones, but that is rare in comparison with slortening from this eause. He alludes to the possibility oi" acerosis eausing impairnent and destruetion of the nearest epiphysial cartilage and arrest of growth at that, the proximal, end, and merely inducing lyyperemia and increase of growth at the other and more distal end. Thus there would be diminution and increase of growth in the same bone, and produeed by the same disease, affecting the two ends in an unequal degree.

The lengthening of the arljacent bones, which, though rare, may be associated either with lengthening or sliortening of the distased bone, is in either case to be attributerl to the accession of blood-supply to the limb, which is in some way broushlit about by the disease, and like the similar ehange in diseased bone, it mist be limited to the growing periot of life.

The associated shorteuing of the aljacent bones may be attributed, as incleed may sometimes in part be that of the diseased bone, to inactivity of the limb. It is most frequently olserved when the disease is in the proximity of a joint, the use of the limb being in sueh cases interfered with inost.

The associated elongation of the arljaeent bone, as in the case of the fibula when the tibia is elongated, may depend upon the aceession of blood extending to the filuula, or, upon tension exerted upon it by the growing tibia, or by both eauses. The resistance of the filmla may, however, limit the elongation of the tibia, or may eause it to assume at curve, as has been observed by Paget and Stanley. In some instances, however, the fibula has not been thus elongated, but has undergone luxation from the upper part of the tibia, its lower end remaining fixel to the tibia, and the upper end being drawn away from it. Two eases of shortening of the tihia were observerl by Humpluy, in one of which the upperend of the fibula was lixated, and projected above its articular surfaee in the tibia, and in the other the lower end projeeted downwards and tonched the ground. Other leformities resulting from the unerpul length of the two bones of one segment of the limb are mentioned.-London Med. Record, July 15, 1879.

\title{
Reproduction of the Tillia after Osteomyelitis.
}

At a reeent meeting of the Geselsclaft der A erzte in Vienna (Allg. Irien. Med. Zeit., No. 24, 1879), Professor Whisuechner presented a lad, aged 17, who in Oetober last liad been taken ill with a severe inflammation of the left leg, from the knee downwards. When admitted into the hospital he was in a very precarious condition, a eomplication with pneumonia had set in, the temperature was pernanently high, and he was much reduced in strength by the constant suppuration. When the patient harl recovered from the pucumonia, Weinlechner proposerl amputation of the leg, as osteonyelitis had manifestly set in ; however, as this was objected to, Weinlechner removed the whole diaplyysis of the tibia, which had in the mean time become neerotie. The extrenity did not present a very sightly appearanee after this operation, as the soft parts of the leg hung loosely about the remaining bone. The suppuration, however, decreased rapidly, and three weeks later the whole empty space was filled by osscous neoformation, which had developed within that short time. Five months have elapsed sinee, 
during whieh time the wound had heen healing. It is now completely cicatrized, with the exception of two very small fistulas. The newly-formed tibia is abont three eentimetres wide in its lower part, it is slightly ablucted and not yet quite consolidaterl, as there is a pscudarthrosis about nine eentimetres above the internal malleolus. The knee-joint is movable, and the leg can be stretehed out and bent without any diffieulty, but suppuratiou has evirlently taken place in the ankle-joint, as the leg is stiff and immovable in that region.-Lond. Med. Record, Aug. 15, 1879.

\section{Fracture of the Coracoid Process.}

Dr. Enward C. Huse, of Roekforl, Ill., records (C'hicngo Med. Journal, August, 1879) the ease of a physician who consulted him on aceount of an injury to his shoulder which he bal sustained an hour before. Upon getting out of bed he stumbled and fell, striking his shoulder against the edge of a loor standing ajar. The pain was so excessive as to render him unconscious for some little time. Upon careful examination of the parts, Dr. Huse was unable to detect any evidence of injury to the bony parts. There was inability to place the laand upon the head, and extreme tenderness on pressure over a limiterl space just inside the acromial end of the clavicle and just bedow it. No crepitns or deformity was at this time observable. Next morning there was eireumscribed tunescence, with considerable impaimnent of function, corresponding to the action of the peetoralis minor and eoraco-brachial museles. It will be remembered that the former is inserted into this process, and also that the conjoined tendon of the latter and of the short head of the biceps arise from its onter border. Crepitation was now quite pereeptible. This was loubtless more from rupture of the trapezoid ligement than the separation of the frigments of bone. Indeed, when the relations of this ligament and also of the conoid are eonsidered, it seems that this fiacture implies the necessary rupture of both of them.

When we observe that the eoracoid process is epiphrseal, and that eomplete osseous muion does not oceur till the twenty-fifth year or even litter, this case may be viewed more as a separation than a fracture, perhaps. Hamilton, however, considers such separations under the nomenclature of frnetures.

The exeeding infrequency of this injury is olvious from a eonsideration of the anatomieal reasons. Nothing but direet violence of a special kind can camse it. Erichsen says only about it dozen cases of fractured coracoid are recorcled. Mr. Lizars denies having seen a well anthenticated ease. Bransby Cooper and Dr. R. Mussey have euth sten one. Hamilton has seen but one.

The patient has but little inconvenienee at present, no treatment further than elevation of the forearn upon the ehest having been employel.

\section{OPHTHALMOLOGY AND OTOLOGY.}

\section{Ophthalmic Migraine.}

Dr. Galezowsis contributed to the June number of the Archives Génerates de Médecine a paper on oplithalmie migraine, or, to use his own definition, "migraine whieh loealizes itself in the organ of sight." Many authors-English, Freneh, and Italian-have mentioned the occurrence of ocular plenomenat as occasional accompaniments of ordinary migraine, but Dr. Galczowski consilers that in a certain number of eases these ocular phenomena constitute the whole 